\title{
The Cultural Ideological Contestation in National Examination
}

\author{
Made Kerta Adhi \\ The Institute of Teacher Education and Training Saraswati
}

\begin{abstract}
The purpose of this research was to find out the forms and the factors leading to the contestation of cultural ideology in National Examination. This research utilized Qualitative Research method and the approach of Cultural Studies. Based on the analysis, it was found that the forms of ideological contestation, specifically, centralistic, prioritizing on the result of cognitive domain, and imaging. The factors which caused consisted of political of education, state policies, and socio-cultural. The implications of this research were (1) There was shifting of educational values into capitalism, (2) The meaning of learning became limited in which it was just purposed at facing National Examination, (3) Educational services have shifted from humanist public services to commodification of education, with the result that honesty was marginalized. Eventhough the government has developed sophisticated system and very tight supervision, if the character of the subjects are not formed and cultured, accordingly, the National Examination stated honest and achievement oriented will be just a slogan. Therefore, the education system needs to be improved. The education paradigm which is more emphasized on the increasing of intellectual intelligence by multiple choice tests and scores needs to be deconstructed by adjusting with Indonesian cultural values based on "Pancasila" as ideological foundation and developing character education to the children from early age.
\end{abstract}

Key words: contestation,national examination, cultural ideology,character

\section{INTRODUCTION}

Education as a cultural practice can never be separated from the performance of dominant structure. The role of the country can not be separated in both the process and the educational quality. In relation with this, the government runs national exam as one of the way to enhance educational quality. Tubagus (in Chan, 2010:41) states that the National Examination is highly required and relevant with the fact to find out quality of education. Moreover, Indonesian president, Joko Widodo decided that the National Examination still exists, due as the benchmarking of the students' progress, so the students are not only being local level fighters but also being able to compete on international level (www.pikiranrakyat.com).

The Goverment Regulation No. 13 Year 2015 and the Regulation of Minister Education and Culture No. 3 Year 2017 are the regulators legitimizing the National Examination still continue until the academic year 2016/2017. Darmaningtyas (2007) states that the authorities certainly do not desire to remove the National Examination because it is a fertile gold mine for material gain, despite giving a huge economic burden on the people and depriving the rights of teachers. The government tends to determine by emphasizing on cognitive domain through multiple choices test with the result in the form of numbers. In addition to computer-based or paper and pencil-based national exams, the students are also required to take School Examination and National Standardized School Examination. This phenomenon is very interesting to be studied in critical education with the approach of Cultural Studies. 
This research specifically purposed to find out the forms and causative factors of ideological contestation of cultural dualism and the implications in the practice of National Examination at SMA Duta Pelangi and SMA Pahlawan Bangsa Tabanan. The method used in this research was Qualitative Research method .The problems were eclectically analyzed by utilizing critical theories in the perspective of Cultural Studies Approach, such as (a) Ideological theory, (b) Social Practice theory, and (c) Critical Education theory. The obtained data were analyzed by utilizing Qualitative Data analysis and interpretative, then presented narratively.

\section{LITERATURE REVIEW}

The ideology behind the cultural dualism is binary opposition as stated by Levi-Strauss (in Ritzer,2009:53) or people of Bali cited by the term "rwa bhineda" (Mantra, 1996: 25; Atmadja, 2010). Cultural dualism are focused on the idea sorting something into two opposite. This sorting can lead to the placement of one thing at the center position, otherwise cause the other to number two or even excluding.

The ideology of cultural dualism which are appear through the texts of laws and regulations dichotomously defined into two categories, specifically success or unsuccessful in National Examination with the slogan " achievement is yes, honesty is a must", as well as tested and untested subject. The implementation is not done by violence, but through the forms of community consent. The dominant class dominate the lower class by using ideology because ideology is an unconscious belief through hegemony. Fakih (2009: 30) states that school and education is not a neutral arena but system and hegemonic structure.

The national examination is deconstructed as important thing. If the exam is not carried out, it will cause bad impact to the students or school, such as students are stated fail or the school can not graduate the students. On the contrary, if the final exam runs with optimal achievement, students, school, and regional area will obtain prestige even an award from Indonesian precident. The achieving schools in the provincial and national level are demanded to be able to maintain the achievement. Bourdieu (in Fashri, 2007: x) states that if the person is on the higher structure, the person will wants to maintain.

When educational institution functionate as hegemonic device, accordingly, it is opened great opportunities to create a form of coercion of ideas, knowledge, and ideology through the mechanism of subtle and invisible violence as symbolic violence (Piliang, 2006: 359; Giddens, 2009: xxii; Bourdieu in Harker, 2009: 120). Behind the hegemony, there is possibility of resistance as a movement to be released from the texts considered discriminatory, inferior to the lower class, and causing injustice.

In the implementation, National Examination constantly sustains dynamics according to the struggle of interests between the dominant structure to the lower class (school community). This condition causes the texts run into adjustment appropriate to the concerns of each structure. The rules which change every year reconstructed based on the wishes and interests of various structures, educational politics, and globalization emancipated and emulated by the quality standard of education. There is interdependence between agents influenced by interests, power, and ideology (Beilharz,2005: 193; Giddens,2009: xviii).

The agents target all students succeed in National Examination practice. This fact occurs continously so it becomes habitus. In achieving the target, there are the performance of capital, ideology, and power. The performance of agents which happen at school involve 
school principles, teachers, officers, students, school committee whereas the performance of agents outside the school are carried out by local goverment and the other stakeholders, such as family, tutoring agency, and social media. Bourdieu (in Harker, 2009: 9) argues that the texts are stated in the equation of $($ Habitus $x$ Capital $)+$ Domain $=$ Practice.

In traditional education, it is stated that the implementation of National Examination runs well. However, critical education views that there are hidden missions behind it, specifically representing interests, ideologies, and serving certain power which cause the other items to be marginalized. Henry Giroux (1993) and Paula Allman (1998) believe that there is political content in all educational activities in which the political content does not represent singular and homogenous idea but empowers the oppressed and transforms injustice. National Examination is the representation of power seizing the school right and hegemonizing the schools. The limitation towards success scores and the type and number of subjects examined are the realization of goverment power dominance. Education has been coopted by the power of state hegemony.The power coming from above will remove the culture that tends to uninformism (Nuryatno,2008: 1; Karim,2009: 123; Safa, 2011: 25).

The assessment of National Examination based on academic standardization is harassment on integrity of human dignity. Academic capability is the cornerstone for education, however the character growth is the foundation for person's life. Education is demanded to provide benchmarks to good attitude and behaviour. Education does not just create persons in accordance with forced quantitative specification, so many things of value in the self are lost. Tilaar (2006: 198) argues that the National Examination just prioritizes cognitive achievements on certain subjects, however the aspects of affective and psychomotor are ignored. National Examination has reduced personal wealth to merely production good that can be standardized hence individuals lose the value as unique person. The achievement establishes the equation which becomes means to spread injustice. Freire (2007: xiii) states that education is for freedom, not for assignment. Education must be the process of independence which is not social and cultural domestication. Meanwhile, Fakih (in O'neil 2008: xvi) states that education is humanizing human beings who are dehumanized due to unfair systems and structures.

The result of ideological contestation were represented not just in the written texts of the regulation, but those were able to be viewed concretely in the practice of National Examination, as the agents at the location of research prioritized tested subjects to untested subjects. In achieving achievements, tangible achievement was prioritized more than intangible achievement. The impacts were prioritized more on result to process and cognitive aspect to affective and psychomotor aspects.

The Regulation of National Education System No. 20 Year 2003 defines that education is conscious and planned efforts to realize environment of learning and learning process, so the students develop self- potential actively to hold religion spiritual power, self- restraint, intelligence, noble character, and skills needed for own-self, nation, and state. Based on the regulation, the texts needs to be deconstructed to return to the natural tendency. Similarly, conducting to the assessment, regardless of name and form, the result is demanded to reflect the elements containing in the regulation proportionally and holistically. The deconstruction of the texts utilize the Deconstruction theory of Derrida. Deconstruction refused to the logocentrism and phonocentrism that overall create binary oposition and hierarchical dichotomy ways of thinking (Piliang, 2003:11; Ratna, 2006: 222).

\section{RESEARCH METHOD}

This research was conducted by utilizing Qualitative Research method and Cultural Studies approach. The Informants who are determined by the sampling techniques of 
purposive and snowball were students, teachers, leaders and businessmen. The data were collected by using the techniques of participatory observation, deep interview, and document study. The analysis data were conducted with qualitative data analysis which consist of data reduction, data display, conclusion, and verification. The result of this research was presented narratively.

\section{RESULTS AND DISCUSSION \\ 4.1 The Forms of Cultural Ideological Contestation of Cultural Dualism in National Examination Practice at SMA Duta Pelangi dan SMA Pahlawan BangsaTabanan}

4.1.1 Centralistic and Prioritizing on the Result of Cognitive Domain

Based on the regulation of National Examination, the National Examination tended to sentralistic which started from tested subjects, tested questions, implementation schedule, forms of examination, and graduation criterias. The tested subjects were reflection of global knowledge examining exact sciences dominantly and prioritizing on cognitive domain. Meanwhile,non-exact sciences were just examined at school. Schools as the lower structure had obligation to follow the established provision, including the subjects examined nationally. The result of the interview with school principle was school in examining subjects tested in national examination refered to the esthablished terms in the Standard Operational Procedure of National Education Standard Agency.

The school did not have authority in determining the subjects tested. The dichotomy between tested and untested subject indicated that there were the separation between public and domestic sector. Untested subjects were as the indication of domestic sector where as tested subjects with "national" label close to public sector valued more dominant and market-oriented. The implication of tested subjects were prioritized and obligated, although the students difficult to answer National Examination (Retnawati, 2017). This resulted untested subjects were marginalized.The comparison of tested and untested subjects in National Examination in Academic Years 2011-2017 can be noticed in table 1.

\section{Tabel 1: The Comparison of Tested and Untested Subjects in National Examination in Academic Years 2011-2017}

\author{
Untested Subjects \\ in Academic Years \\ $2011-2017$
}

Natural and Social Science

Department

1. Religion

2. Civics Education

3. History

4. Art and Culture

5. Physical Education and sport

6. Balinese

7. Character Education
Tested Subjects

in Academic Years

$2011-2017$

Source : Standard Operational Procedure of National Education Standard Agency for

National Examination in Academic Years 2011-2017

Explanation :*) The subjects must be taken in 2011, however one subject could be chosen according to the department. 
The tested subjects as public sectors were given more handling than untested subjects as domestics sectors because the tested subject with national label had more risks on the unsuccessfulness and imaging impact. Moreover, those with hard category, such as Biology, Math, Chemistry, Physics, English, and Indonesian for Natural Science department and Math, Economics, Georaphy, Sosiology, Indonesian, and English for Social Science department (Standard Operational Procedure of National Education Standard Agency for National Examination in Academic Years 2011and 2017). The preferred subjects were indicated by means of National Examination data in 2011 in which the everage scores of school's values for Social Science department were 8.53 and 8.89 for the value of National Examination where as for Natural Science department were 8.79 for School value and 9.17 for the value of National Examination (Kerta Adhi, 2013: 305). The data of National Examination in 2017 indicated that the everage results were 67.68 for School Examination and 88.17 for National Examination for Natural Science department whereas the obtained results for Social Science department were 67.51 for National Examination, 85.17 for School Examination, and 87.83 for National Based School Examination (Archives of SMA Duta Pelangi). Meanwhile, the everage scores of social department at SMA Pahlawan Bangsa reached 43.69 for National Examination, whereas each for School Exam and National Based School Exam were 79.80 and 78.87. The data indicated that the values of National Exam were less than School Exam and National Based School Examination. Those were as the sign of behaviour change in which National Examination did not determained the graduation and the implementation was based on computer.

The tested subjects tended more difficult than untested subjects. Those measured cognitive aspect with the result that the students concentrated more on the tested subjects. National Examination constructed social stratification, specifically the differentiation offered impact to the difference of attitude, behaviour, and students' action to the teachers who teach tested subjects and who teach untested subjects (Damsar, 2011: 141).

The hard subjects were just able to give information in relation to cognitive capability whereas the non-cognitive were not able to be evaluated, moreover the exam was just done temporally and concisely. National examination carried out by the government tended based on formal logical standard than material logical. National Examination was only viewed on the form but it was not accordance with content philosophy and students' need in determining learning result. The purpose of learning at school was constructed to prepare and face National Examination. The educational meaning purposed to develop thinking, soul, and body has been reduced by intellectual western mindset. Karim (2009: 146) and Andyka ( in Safa, 2011: 53) state that the National Examination evidently confine the space for potential students intelligence, possibly it opposes human nature. According to this fact, the purpose of learning at school was formed more on preparing and facing National Examination or learning for the test. The spirit of students critical reasoning development became restricted. Future expectations of the students were hanging only on a passing grade or success.

This fact was accordance with Indonesian intellectual people in developing country which are generally grown through schooling system. Consequently, educational system prioritized on exact science and technology and it was not influenced by classical education. Values of education must be perceived as a necessity, not something desirable as an element of personal formation (Drost, 2008: 149).

\subsubsection{Imaging}

In the reserach location, students or schools carried out maximal efforts to succeed because the success was the interest and cosumtive need. The consumtion was not just to fullfil value for human's utility and basic need but related with symbolic meaning to 
indicate class, status, prestige, as means to state social's differentiation, and mapping. Irawan (2015) argues that schools understand the mapping for transcribing the extent of National Examination school rankings. Accordingly, the achievement was not merely achievement but also the prestige in stages from students/schools / students' parents and the regions. The prestige of schools and or regions as symbolic meanings to distinguish the capability of students or schools.

\subsection{Causative Factors of Ideological Contestation of Cultural Dualism in National Examination Practice In SMA Duta Pelangi and SMA Pahlawan BangsaTabanan}

\subsubsection{Political Education and State Policy}

The occurrence of ideology contestation, particularly achievement and honesty at the research location due to the state policy stating that the National Examination aimed at achieving standarization of national education. National Examination as a public policy is stated in the form of regulation (Masduki, 2008: 8)

The examination was standardized according to logical capitalism. The quality of Indonesian education was established based on capitalistic decision makers, for instance, the Competency Based National Examination. The government always argues that the standard of National Examination by assigned values to execute students' graduation based on the comparison of Indonesian educational quality to the other countries (global capitalism). There was competition of ideology as an implication of education. Ade Hermawan (in Safa, 2011: 25) states that education in globalization era is market-oriented. Globalization leads the shifting function of educational institution to be business, focusing on the issue of National Examination, and viewing educational quality standard just by measuring students'cognition.

The regulation of texts were explained in detail by Educational National Standard Agency in the form of Standard Operational Guidelines of National Examination. The texts contained meaning that there were structurally hegemonic process and cultural dualism ideology. The government, related institutions, communities, and students' parents also participated in successing the examination. Both public and private schools were obligated to follow the National Examination.

\subsubsection{Socio-Cultural}

Students and other education implementers in the location of research stated of feeling unsuccessful if the obtained values were low, especially the students became inferiority likewise the parents. If the presentage was marginal, the school burdened morally of being claimed to fail to educate children. The failure was often utilized as indicators of school quality. The rank of obtained results were also used as an indicator of educational quality in the region. Accordingly, the agents tried to reach the achievement to enhance the social cultural status, furthermore students can be accepted in the favorite level of education. Zamroni (2007: 239) argues that reaching achievement in the National Examination was backgrounded by unvisible cultural factors. Therefore, the agents conducted guadiance for the students both at school and outside school. In the implementation, students subtly cooperated in answering questions moreover the supervision was loose.

\subsection{The Implication of Ideological Contestation of Cultural Dualism in the Practice of the National Exam at SMA Duta Pelangi and SMA Pahlawan BangsaTabanan}

The implications of this research were experienced by school principles, the entrepreneurs of the tutoring institution, the agents, and quality of education.

The implication to the school principle was experiencing symbolic violence in implementing the policy, with the result that the principal carried out some efforts, such as prioritizing the tested subjects, making a special budget, and providing guidance to 
teachers/supervisors and students. The hegemonic teachers had to follow Standard Operational Guideline but gentle resistances were done by tutoring, loosening supervision, and assisting to provide answers. Those were caused by the rights and authority of teachers in accordance with the law need to be noticed, moreover the teachers who had been certified as an educator.

The implications for the entrepreneurs of the tutoring institution were economically benefited. In addition, the students became more prepared normatively. However, beyond that, there were the shift of educational values into capitalism. The involvement of independent monitoring teams in research location indicated that implementation obtained legitimacy.

The implication for the agents continued to the process and result of learning. The meaning of learning became limited and shallow. Educational services had shifted from humanist public services to commodification of education. The orientation of the National Examination has changed from paper and pencil-based test to computer-based test which caused anxiety to the students (Sulistyaningsih, 2016). In addition, National Examination prioritized more on result to process, cognitive aspect to affective and psicomotor aspects, logical and mathematical intelligence, learning for the test to comprehensive material comprehension, uniformity/ standard to diversity, rich individuals to the poor,central government/ sentralistic to school autonomy, and reaching success but ignoring failure.

The implications for the quality of education were biased. In the location of research, the implementation prefered to the tangible achievement in the form of numbers/scores interpreted as achievement than the process in achieving. This condition implicated to the educational quality. A high score was not significant to improve the quality of education when it was obtained by using incorrect ways. Educational quality was not only viewed from the indicators in the form of numbers/ scores, but also from the intangible indicators, specifically honesty, in accordance with the slogan "achievement is yes, honesty is a must".

Globalization by Giddens has brought people to Knowledge Based Society, with the result that knowledge is the standard in all way of life. Cognitive power supported by materialistic attitude without any sense of power and physical power causing human life to dwell only on number by number, the success is numbers, fate is determined by numbers, so the child becomes burdened (Lutfi Lazuardy in Safa, 2011: 85; Chan And Tuti T Sam, 2010: 39).

The texts of National Examination need to be deconstructed because the texts must be constructed from Indonesian cultural values based on "Pancasila" as ideological foundation and not capitalism. The sovereignty of the teachers/schools need to be restored according to the habitus. Beside that, the students have to be valued as subject of uniqueness. Curriculum need to be reviewed and children should not be only stuffed with knowledge in the establishment of intellectual intelligence, but also be equipped with character education from early age.

\section{CONCLUSION}

Ideological contestation were represented on written texts of the regulation and viewed concretely in the practice of national examination. In the location of research, the agents prioritized tested subjects to untested subjects because the tested subjects had higher value of indicator level, more risks on the unsuccessfulness, and imaging impact. National Examination as a dominant structure product had power in determining the fate and the future of the agents. National Examination was established by National Education Standard Agency with the slogan "achievement is yes, honesty is a must". However, in the implementation, there were discriminations towards the achievement or the value. The agents prioritized achievement than honesty.The National Examination has become a fetter 
because the parties involved inside did not really act according to the Standard Operational Guideline but tended to deviate. Therefore, it is necessary that the texts need to be deconstructed by changing the learning system and the judgments not merely seen from the sophistication of technology but the humanistic learning process. In addition, prioritizing character education to the children from early age continuously and consistently need to be carried out.

\section{REFERENCES}

[1] Atmadja, Nengah Bawa. "Sekolah (Rintisan) Bertaraf Internasional Sebagai Arena Sosial Melanggengkan Ketidak Adilan Bagi Kaum Miskin (Perspektif Teori Kritis)". Media Komunikasi FIS. Edisi Khusus Pendidikan Ekonomi Vol. 9 No.1 Juni 2010. ISSN 1412-8683. Singaraja: FIS Undiksha ( 2010)

[2] Beilharz, Peter.Teori-teori Sosial. Yogyakarta: Pustaka Pelajar.(2005)

[3] Chan, Sam M dan Tuti T Sam. Analisis SWOT: Kebijakan Pendidikan Era Otonomi Daerah. Jakarta: Raja Grafindo Persada. (2010)

[4] Damsar. Pengantar Sosiologi Pendidikan.Jakarta: Kencana Prenada Media. (2011)

[5] Darmaningtyas. Pendidikan Rusak-Rusakan. Yogyakarta: LKiS. (2007)

[6] Drost, SJ. J.I.G.M. Sekolah: Mengajar atau Mendidik. Jogyakarta: Kanisius.(2008)

[7] Fakih, Mansour. Runtuhnya Teori Pembangunan dan Globalisasi. Yogyakarta: Insist Press. (2009)

[8] Fashri, Fauzi. Penyingkapan Kuasa Simbol: Apropriasi Reflektif Pemikiran Pierre Bourdieu. Yogyakarta: Juxtapose (2007)

[9] Freire, Paulo. Politik Pendidikan: Kebudayaan Kekuasaan dan Pembebasan. (Agung Prihantoro dan Fuad Arif Fudiyartanto Penerjemah).Yogyakarta: Pustaka Pelajar (2007)

[10] Giddens, Anthony.Problematika Utama dalam Teori Sosial: Aksi, Struktur,dan Kontradiksi Dalam Analisis Sosial. (Dariyatno, Penerjemah). Yogyakarta: Pustaka Pelajar (2009)

[11] Harker, Richard dkk. (Editor). (Habitus $x$ Modal)+Ranah = Praktik: Pengantar Paling Komprehensif Kepada Pemikiran Pierre Bourdieu. Yogyakarta:Jalasutra (2009).

[12] http://edukasi.kompas.com. "Keberhasilan UN Hanya untuk Kepentingan Politik" Diakses Tanggal 20 Desember (2010)

[13] Irawan, Candra."The National Examination And The Quality Of Education Mapping" Indonesian Journal of Educational Review p-ISSN 2338-2015 | e-ISSN 2335-8407 Vol.2, No.1, p 97-105, March ( 2015)

[14] Karim, Muhamad. Pendidikan Kritis Transformatif. Yogyakarta: Ar-Ruzz (2009)

[15] Kerta Adhi, Made. "Pengutamaan Kebijakan UN dan Representasinya pada Sistem Manajemen Pendidikan di SMA Tabanan". Disertasi. Denpasar: Program Pascasarjana UNUD (2013)

[16] Mantra, IB. Landasan Kebudayaan Bali. Denpasar: Yayasan Dharma Sastra (1996)

[17] Masduki dan Muzayin Nazaruddin (Editor). Media, Jurnalisme dan Budaya Populer. Yogyakarta: Prodi Komunikasi Universitas Islam Indonesia dan UII Press (2008)

[18] Nuryatno, Agus. Mazhab Pendidikan Kritis: Menyingkap Relasi Pengetahuan Politik dan Kekuasaan. Yogyakarta: Resist Book (2008)

[19] O’neil, William F. Ideologi Ideologi Pendidikan. Yogyakarta: Pustaka Pelajar (2008)

[20] Piliang, Yasraf Amir. Hipersemiotika, Tafsir Cultural Studies Atas Matinya Makna. Yogyakarta: Jalasutra (2003)

[21] Piliang, Yasraf Amir. Dunia Yang Dilipat: Tamasya Melampaui Batas-Batas 
Kebudayaan .Yogyakarta: Jalasutra (2006)

[22] Ratna, Nyoman Kutha.Teori, Metode,dan Teknik Penelitian Sastra. Yogyakarta:

Pustaka Pelajar (2006)

[23] Retnawati, Kartowarigan, Arlinwibowo,Sulistyaningsih. "Why are the Mathematics National Examination Items Difficult and What is teachers Strategy to Over come it?. International Journal of Instruction. Vol.10. No.3 ISSN 1694-609X pp 257-276.( 2017)

[24] Ritzer, George.Teori Sosial Postmodern. Yogyakarta: Kreasi Wacana (2009)

[25] Safa, Aziz (Ed.), Tim Kreatif LKM UNJ. Restorasi Pendidikan Indonesia:Menuju Masyarakat Terdidik Berbasis Budaya. Jogyakarta: Ar-Ruzz Media (2011)

[26] Sulistyaningsih,Eny. "Student Anxiety Facing Computer Based Test (CBT) System of National Examination". Proceeding of $3^{\text {rd }}$ International Conference on Research. ISBN 978-602-74529-0-9 p 113. (2016).

[27] Tilaar, HAR. Standarisasi Pendidikan Nasional: Suatu Kajian Kritis. Jakarta: Rineka Cipta (2006)

[28] www.pikiran-rakyat.com. Arie C Meliala. "Presiden Putuskan Ujian Nasional Tetap Ada" dalam Pikiran Rakyat. Diakses Tanggal 10 April ( 2017)

[29] Zamroni. Pendidikan dan Demokrasi Dalam Transisi. Jakarta: PSAP Muhammadiyah (2007) 